\title{
Anthralin: the primary products of its redox reactions
}

\author{
Malgorzata Czerwinska, Adam Sikora, Piotr Szajerski, Jacek Zielonka, \\ Jan Adamus, Andrzej Marcinek* \\ Institute of Applied Radiation Chemistry, Technical University, 90-924 Lodz, Poland \\ Krzysztof Piech, Pawel Bednarek, Thomas Bally* \\ Department of Chemistry, University of Fribourg, CH-1700 Fribourg, Switzerland
}

\section{Supporting Information, Part 1}

Full citation for the Gaussian 03 Program (Reference 49):

Frisch, M. J.; Trucks, G. W.; Schlegel, H. B.; Scuseria, G. E.; Robb, M. A.; Cheeseman, J. R.; Montgomery, J. A.; Vreven, T.; Kudin, K. N.; Burant, J. C.; Millam, J. M.; Iyengar, S. S.; Tomasi, J.; Barone, V.; Mennucci, B.; Cossi, M.; Scalmani, G.; Rega, N.; Petersson, G. A.; Nakatsuji, H.; Hada, M.; Ehara, M.; Toyota, K.; Fukuda, R.; Hasegawa, J.; Ishida, M.; Nakajima, T.; Honda, Y.; Kitao, O.; Nakai, H.; Klene, M.; Li, X.; Knox, J. E.; Hratchian, H. P.; Cross, J. B.; Adamo, C.; Jaramillo, J.; Gomperts, R.; Stratmann, R. E.; Yazyev, O.; Austin, A. J.; Cammi, R.; Pomelli, C.; Ochterski, J. W.; Ayala, P. Y.; Morokuma, K.; Voth, G. A.; Salvador, P.; Dannenberg, J. J.; Zakrzewski, V. G.; Dapprich, S.; Daniels, A. D.; Strain, M. C.; Farkas, O.; Malick, D. K.; Rabuck, A. D.; Raghavachari, K.; Foresman, J. B.; Ortiz, J. V.; Cui, Q.; Baboul, A. G.; Clifford, S.; Cioslowski, J.; Stefanov, B. B.; Liu, G.; Liashenko, A.; Piskorz, P.; Komaromi, I.; Martin, R. L.; Fox, D. J.; Keith, T.; Al-Laham, M. A.; Peng, C. Y.; Nanayakkara, A.; Challacombe, M.; Gill, P. M. W.; Johnson, B.; Chen, W.; Wong, M. W.; Gonzalez, C.; Pople, J. A., Gaussian 03, Rev B.01, Gaussian, Inc., Pittsburgh, 2003.

Figure S1 Molecular orbitals ${ }^{1}$ involved in the electronic transitions of $\mathbf{1}^{\bullet-}$ as predicted by the TD-DFT calculations listed in Table 1.

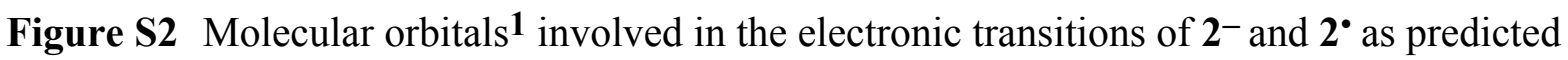
by the TD-DFT calculations listed in Tables 2 and 3.

Figure S3 Molecular orbitals ${ }^{1}$ involved in the electronic transitions of $\mathbf{1}^{\text {'•+ }}$ as predicted by the TD-DFT calculations listed in Table 4

Figure S4 Most favorable calculated pathway for the conversion of $\mathbf{1}^{\bullet+}$ to $\mathbf{1}(\mathrm{enol})^{\mathbf{}}{ }^{+}$.

Numbers indicate relative B3LYP/6-31G* energies, including ZPE differences, in $\mathrm{kcal} / \mathrm{mol}$, italic numbers are for transition states between the depicted structures.

(1) MOPlot, Version 1.85 for Windows 2000/XP, Mac OS X, Linux. Available for free from the authors at http://www-chem.unifr.ch/tb/moplot/moplot.html 
$-6 a_{2}$

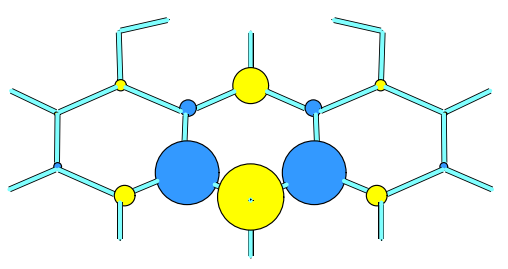

$29 a_{1}$
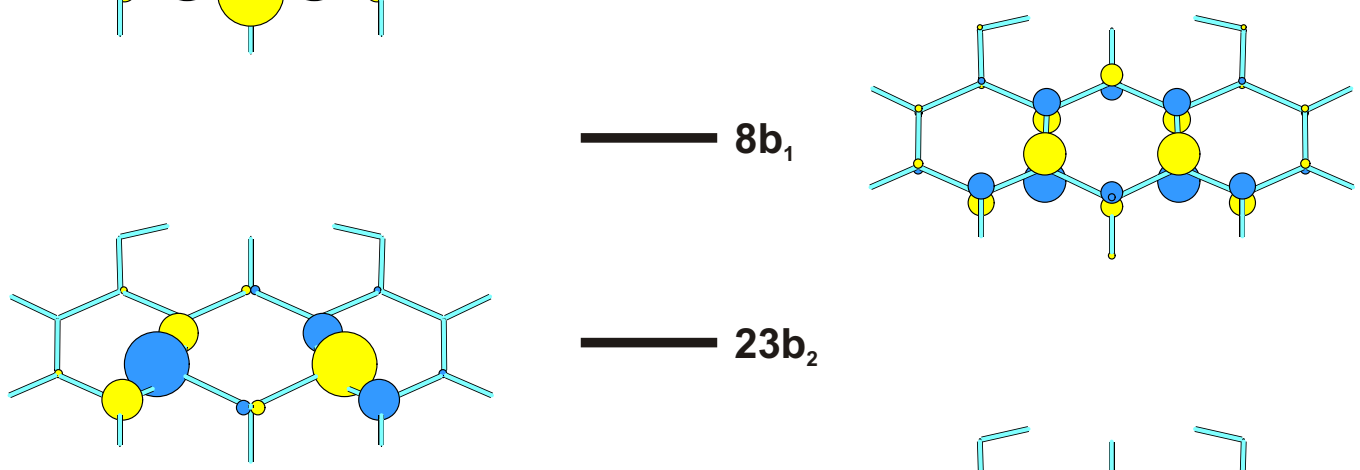

$23 b_{2}$
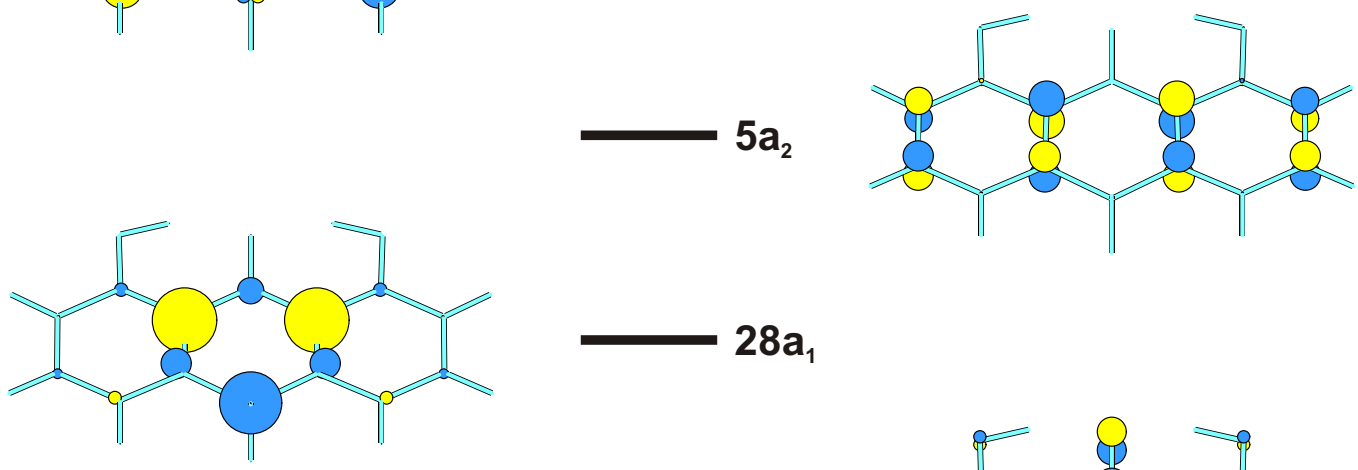

$28 a_{1}$
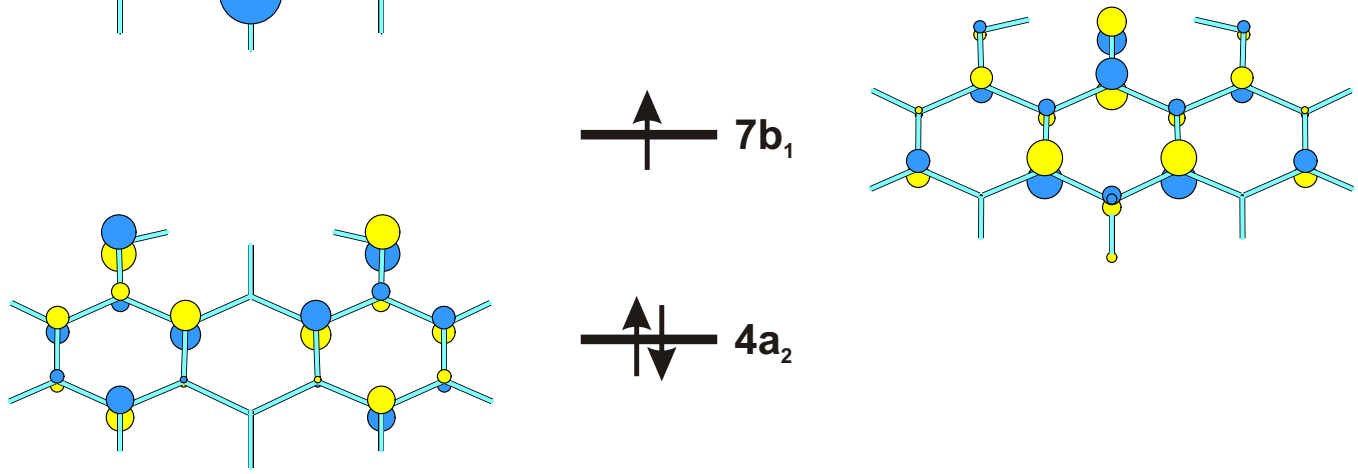

$\frac{4}{1 V} 4 a_{2}$

Figure S1: Molecular orbitals involved in the electronic transitions of $1^{\bullet+}$ as predicted by the TD-DFT calculations listed in Table 1 . 


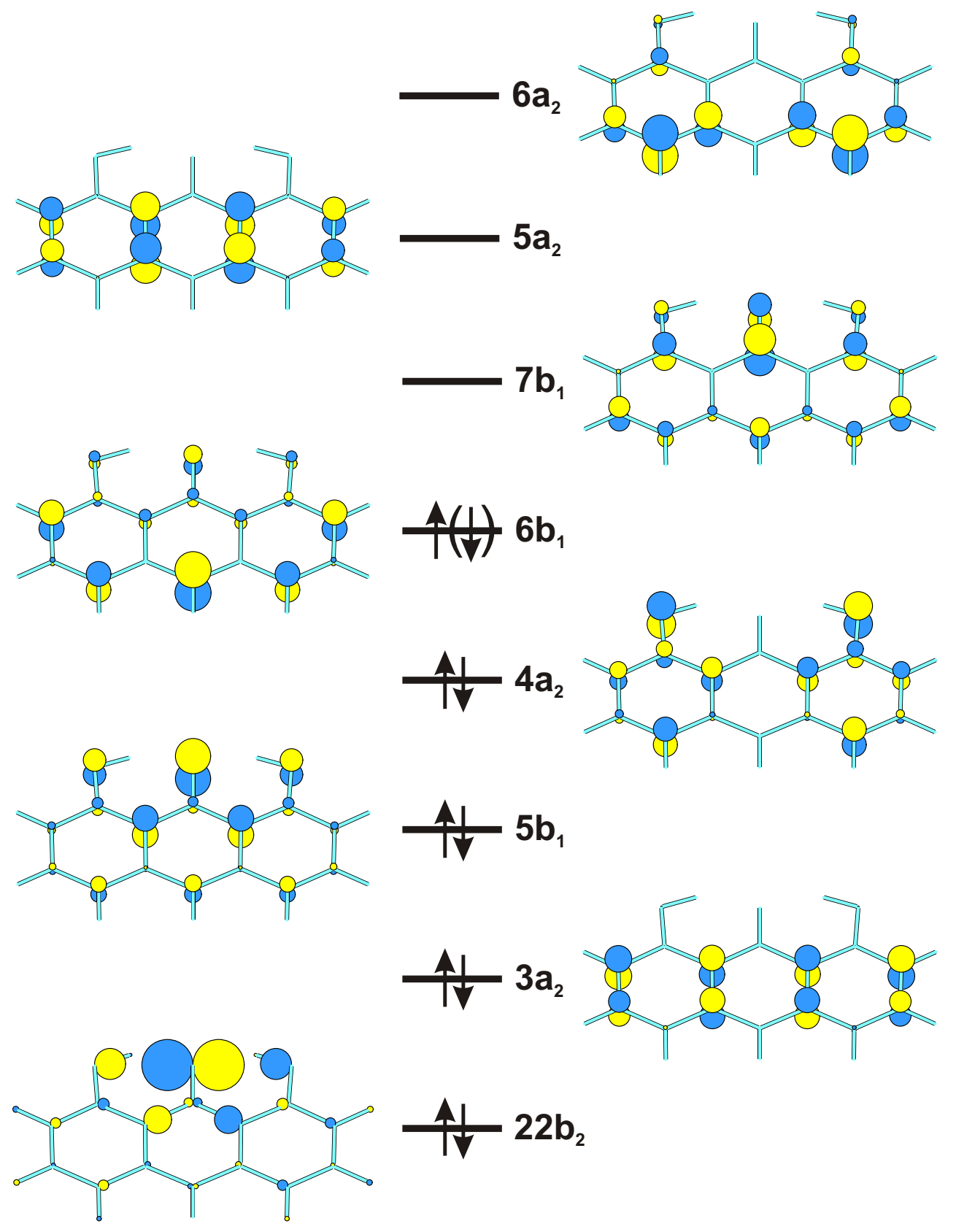

Figure S2: Molecular orbitals involved in the electronic transitions of $\mathbf{2}^{\circ}$ and $\mathbf{2}^{-}$as predicted by the TD-DFT calculations listed in Tables 2 and 3. 

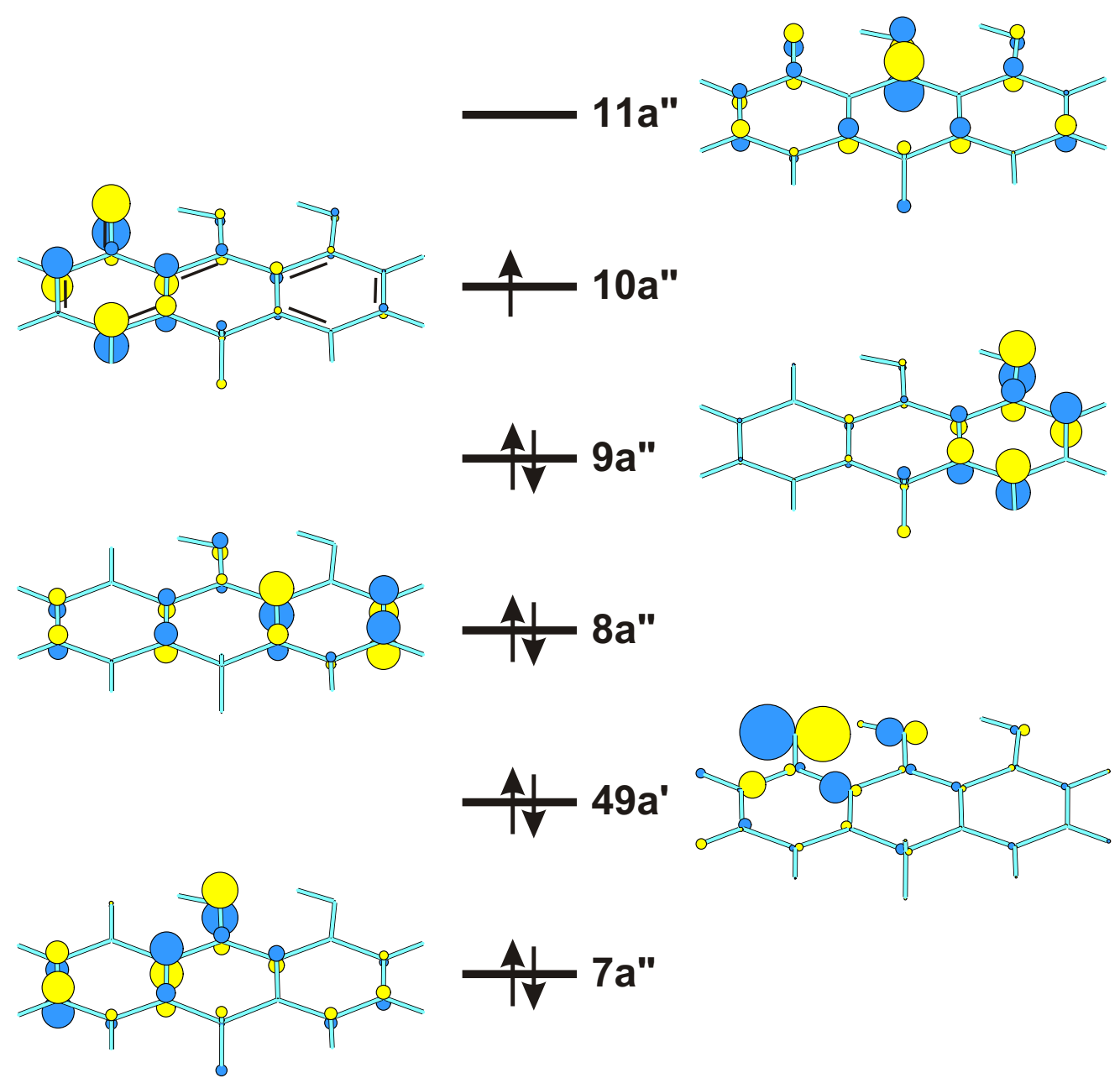

Figure S3: Molecular orbitals involved in the electronic transitions of $1^{1 \cdot+}$ as predicted by the TD-DFT calculations listed in Table 4 . 


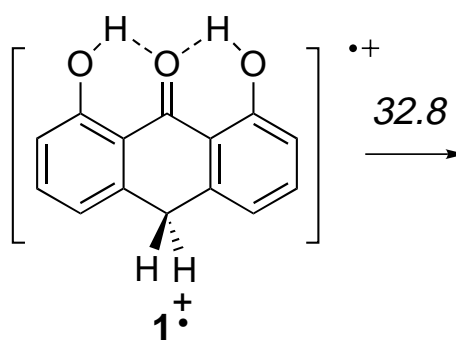

(0)

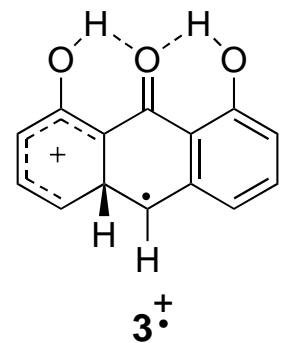

30.9

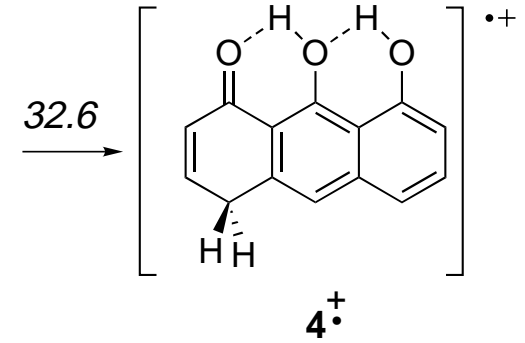

$-6.4$

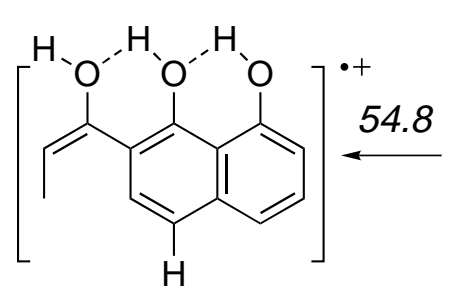

1-enol : $-13.4$

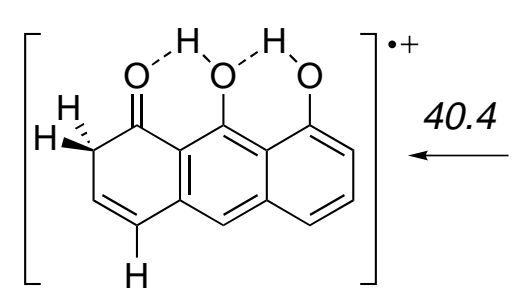

$6^{+}$

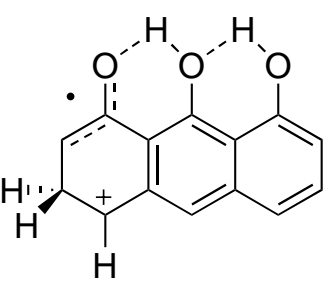

$5^{+}$

Figure S4: Most favorable calculated pathway for the conversion of $\mathbf{1}^{\mathbf{0}^{+}}$to $\mathbf{1}(\mathrm{enol})^{\bullet+}$. Numbers indicate relative B3LYP/6-31G* energies, including ZPE differences, in $\mathrm{kcal} / \mathrm{mol}$, italic numbers are for transition states between the depicted structure 